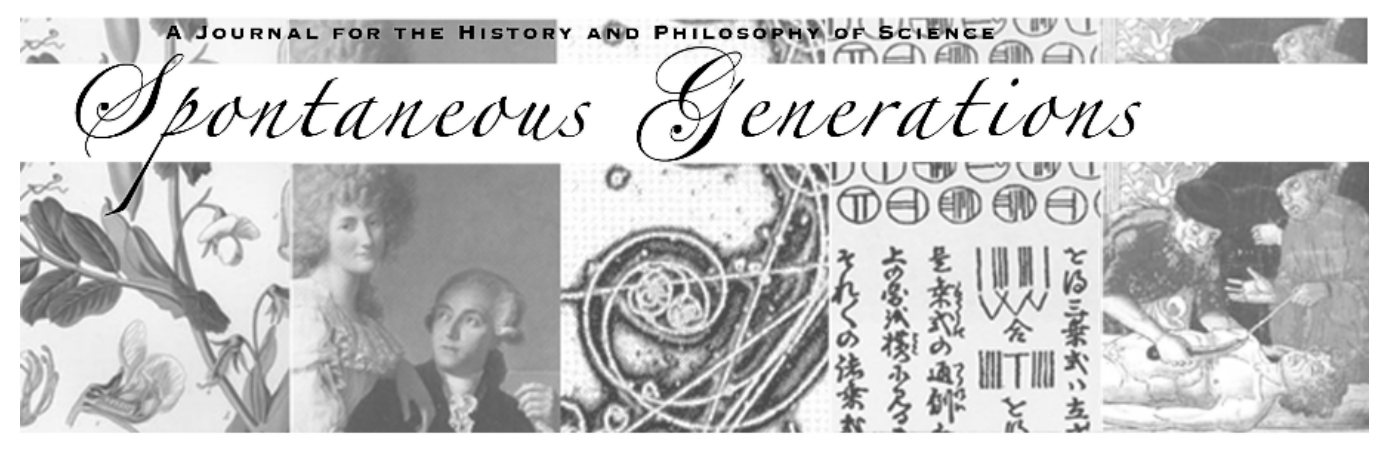

\title{
The Evolutionary Economics of Science
}

Author(s): Marion Blute

Source: Spontaneous Generations: A Journal for the History and Philosophy of Science, Vol. 7, No. 1 (2013) 62-68.

Published by: The University of Toronto

DOI: 10.4245/sponge.v7i1.19562

\section{EDITORIAL OFFICES}

Institute for the History and Philosophy of Science and Technology

Room 316 Victoria College, 91 Charles Street West

Toronto, Ontario, Canada M5S 1K7

hapsat.society@utoronto.ca

Published online at jps.library.utoronto.ca/index.php/SpontaneousGenerations ISSN 19130465

Founded in 2006, Spontaneous Generations is an online academic journal published by graduate students at the Institute for the History and Philosophy of Science and Technology, University of Toronto. There is no subscription or membership fee. Spontaneous Generations provides immediate open access to its content on the principle that making research freely available to the public supports a greater global exchange of knowledge. 


\title{
The Evolutionary Economics of Science ${ }^{*}$
}

\author{
Marion Blute ${ }^{\dagger}$
}

\begin{abstract}
This short paper is about the generalized evolutionary approach to the economics of science (and technology). Stephen Toulmin and David Hull are pioneers of the former rather than Karl Popper whose falsification thesis was sociologically naive. Useful directions for the future would go beyond the generalities of variation, transmission and selection towards making more explicit use of Darwin's "two great principles." The first is "the unity of types" i.e. common descent by employing phylogenetic methods to answer historical questions. The second is "the conditions of existence" i.e. natural selection by making use of general principles of evolutionary ecology and socioecology to answer questions about why something evolved.
\end{abstract}

\section{INTRODUCTION}

While the "economics of science" can be interpreted in a variety of ways, the approach taken here is to cast the topic in a generalized Darwinian evolutionary framework (Aldrich et. al. 2008)-i.e. the evolutionary economics of science.

The most interesting segment of the rebellion against the narrowness of neo-classical economics is the generalized Darwinian evolutionary approach which extends Darwinism beyond its original biological sphere of application (e.g. Boulding 1978, 1981; Guha 1981; Nelson and Winter 1985; Rothschild 1990; Mokyr 2002; Murmann 2003; Beinhocker 2006; Hodgson and Knudsen 2010). In parallel with this scholarly work has been the development of a generalized Darwinian evolutionary approach to Science and Technology Studies (e.g. Toulmin 1972; Steadman 1979; Basalla 1988; Hull 1988; Petroski 1992; Ziman 2000; Mokyr 2002; Jensen et. al. 2003; Blute and Armstrong 2011). And if we were to include the same approach to culture and social organization more generally (which often includes references to economics and science and technology studies and other subject matters like archaeology and linguistics as well), much of it stemming from the pioneering work of Gerard et. al. (1956) and Cavalli-Sforza and Feldman (1981), the list would be very much longer indeed.

Received 25 March 2013.

$\dagger$ Marion Blute is a Professor Emeritus of Sociology at the University of Toronto. Her research interests are in evolution (biological, sociocultural and gene-culture coevolution) as well as science studies. Her monograph on Darwinian Sociocultural Evolution: Solutions to Dilemmas in Cultural and Social Theory was published by Cambridge University Press in 2010. 
However, restricting ourselves to evolutionary economics and evolutionary science and technology studies, we can see that some individual hybrids have been formed. For example, although I have placed them in the economics list, Mokyr and Murmann really belong in both because Mokyr writes about the economic consequences of the evolution of useful knowledge and Murmann takes a coevolutionary approach to both firms and technology (as well as national institutions). The existence of a few such hybrids suggests the possibility of the future emergence of a more robust and distinct hybrid scholarly species-an evolutionary economics of science and technology or an evolutionary economics of science and technology.

\section{Karl Popper}

I am sometimes asked-particularly by philosophers of science-why I do not usually turn to Karl Popper rather than, or in addition to, Stephen Toulmin and David Hull as a founder of the evolutionary approach to science. However, we are talking about generalizing Darwinism and throughout much of his career Popper thought that evolution was not falsifiable and hence not a scientific theory $(1959,1962)$. He later moderated his view somewhat (1972, 1974), coming to think of Darwinism as "a metaphysical research program," but I suspect that Ruse's (1977) sensitive reading of Popper is basically correct. Popper's emphasis on goal-directed behavioural change as playing the leading role in evolution suggests that he never really (at least emotionally) accepted the Darwinian revolution. More recent research using ancestral state reconstruction methods on polymorphisms and polyphenisms found that there is in fact no clear tendency for genes to be leaders or followers in evolutionary change overall (Schwander and Leimar 2011) which does however support the wisdom of including both in a definition of evolution by natural selection (Blute 2008). It is also the case that genetic programmes, incorporating as they often do much adaptive phenotypic plasticity, may be thought of as purposes in an evolutionary sense. But since neither they nor human minds (including those of scientists) are prescient- as Donald Campbell so often put it-such facts do not negate the premise that statistically, they ultimately arise blindly.

Popper's ethos that scientific knowledge is always open to revision is generally a sound one, but not universally true. Few serious scientists, after all, think that we will someday discover that the earth is flat; that natural selection is not, in fact, a cause of evolutionary change; or that no species has ever descended with modification from any other species. Popper's claim that falsificationism-selection against- is akin to the logic of evolutionary biology is even more clearly false. Instead, the theory of evolution in genetical form understands evolutionary change to be a matter of change in relative frequencies or proportions; thus it makes no sense to prioritize selection against over selection for, or for that matter even to distinguish between them. 
It is true that the elementary logic of statistical testing in science rests on falsificationism. However, any idea that falsificationism is part of the everyday practice of science would be particularly sociologically naive. In fact, it is well known that there is a large bias in science against the publication of negative results (Sterling 1959; Sterling et. al. 1995; Ioannidis 2005; Fanelli 2010; 2012). Researchers want to discover, reviewers want to review, editors want to publish and readers want to read what is the case, not what is not. At every stage of the process, negative results are filtered out. As an illustration, in Table 1 I have briefly stated the thesis of the eleven items published in the current issue of Trends in Ecology and Evolution; the thesis of ten out of eleven items is positive and only one (item 7) is negative. If you think this result is unique to the particular local population of articles included, feel free to test it with the current issue of your own favourite journal. The bias against publishing negative results in science is so strong that it has attracted attention from major journals, which are currently very much concerned with the distortion this produces in the scientific literature (Yong 2012).

1. Ethnobiology is the missing link in ecology and evolution

2. Learning does impact selection-driven speciation

3. Impact of learning on speciation is unclear

4. There are factors determining the success of crowd funding in science

5. Cryptic mutations, particularly at third codon position, do matter in speciation and are useful for bar coding

6. Density-dependent processes do structure biodiversity

7. The hypothesis that intermediate levels of disturbance maximize biodiversity is false

8. Introduced parasites do alter food webs although predicting the degree is difficult

9. Conservation conflicts can be managed

10. Higher levels of heterogeneity of selection do give longer-term pest or pathogen control

11. State-based-prediction-theory is an improvement on foraging theory

Table 1. Thesis of all items published in order in Trends in Ecology and Evolution (Tree), 28(2) February 2013 issue.

\section{Directions for the eVolutionary economics of SCIENCE}

There have been some differences of opinion about whether extensions of Darwinism beyond its original biological sphere of application are analogies, a generalization so that all are tokens of the same general type-selection processes-or whether they have all simply descended culturally from 
Darwinism. On whichever view, progress will likely be achieved by moving beyond the generalities of sociocultural variation, transmission by social learning and selection, and take cues from what are (in addition to population genetics), the two most important research programmes in evolutionary biology: taxonomy and evolutionary ecology/socioecology.

The first research programme corresponds to the first of Darwin's "two great principles"-"the unity of types" or common descent, which classifies entities into groups within groups and reveals the historical affinities among them. Phylogenetic methods are capable of answering historical questions about where (and sometimes when) something came from. I am unaware of any formal applications of such in evolutionary economics or evolutionary science and technology studies, although there is no reason why such methods could not be applied to economic/scientific and technological information, behaviours, social roles or statuses, organizations, institutions, etc. Applications of such phylogenetic methods have become very well developed in the last couple of decades in other social science disciplines including linguistics, archaeology, and cultural anthropology (for an overview see Blute 2010 Chpt. 2; for some recent examples see Buckley 2012; Walker et. al. 2012; Altschuler et. al. 2013).

The second research programme corresponds to Darwin's second great principle, "the conditions of existence," or natural selection. Evolutionary ecology and socioecology seek to complete Darwin's theory by finding answers to the question of what characteristics selection favours under what ecological and/or social conditions, whatever their historical affinities. Working within this research programme in science and technology studies has been a major personal research interest; it is the research programme that shares the strongest affinity with traditional economics, albeit with some fundamentally different assumptions. First economics has traditionally taken an individual-based, forward-looking teleological perspective, assuming that individuals act so as to maximize their expected utility (and play social games rationally). The evolutionary approach instead takes a population-based, backward looking teleonomic (Pittendrigh 1958) perspective, positing that selection acts so as to favour individuals that maximize fitness (and play social games rationally). Secondly, while economics speaks of maximizing utility-whatever it is that one values-in practice economists almost always define utility as wealth and income. In contrast, biological evolutionists hold a variety of interpretations of fitness, which is sometime defined as maximizing survival and reproduction, and sometimes as the number of surviving offspring, and sometimes-as I suggest-as the production of grand offspring, because the life cycle of an organism which grows and produces offspring has not been reproduced or replicated until those offspring in turn have grown and produced offspring. Thirdly, students of science follow the nineteenth century sociologist Max Weber in assuming that what is sought or selected is not only limited to 
the receipt of wealth and income but also includes power or status; they have thus concluded that in acquiring and disseminating knowledge, scientists seeks "credit" (Hull 1988). Yet another difference between traditional economics and evolutionary economics is that evolutionary ecology/socioecology has a closer link to physics and chemistry; adaptations can evolve in response to the physiochemical features of the environment (including energy content, sizes, numbers, spatial and temporal distribution of resources, antagonists, social partners and victims).

Beyond those differences, this combination of economic, game theoretic and physiochemical principles can be used to predict the conditions under which scientists should be favoured to obtain credit by consuming (acquiring knowledge by doing research) or producing (publications and students); by spending on these or investing in waiting, moving or changing topics or fields in order to do so; by functioning as fast specialists or as longer, slower generalists; by devoting themselves to their research, writing and teaching; or by engaging in social interaction with peers; by bet hedging as in index funds and dollar cost averaging or being adaptively phenotypically plastic, switching among strategies according to conditions; by devoting themselves to their research, writing and teaching or by defending their science, publications and students against antagonists (e.g. Blute 2003; 2010 Chpts. 3 \& 4; 2011). Attention has often been paid to the receipt of credit in science by focusing on acknowledgments in citations and by students. I have often thought, however, that it would be at least as interesting to follow through the full cycle of reproduction or replication in science by looking at citations to the papers that cite them and at the students their students produce-i.e., at grandpapers and grandoffspring.

In his famous talk asking what economists can learn from evolutionary theorists, Krugman (1996) was correct in his observation that at least some evolutionists are "optimization and equilibrium kinds of guys" like him. Evolutionary ecologists/socioecologists do indeed tend to be so, but only within a broader framework that contains other research programmes. The framework of evolutionists is one that acknowledges the importance of constraints, chance, and history as well as selection; it recognizes that it is selection acting on variations in populations that results in optimization and rational game-playing, rather than individual prescience. I think it is no accident that the word population appears once in Krugman's essay while the word individual appears twenty-four times.

\author{
MARION BLute \\ Sociology, University of Toronto at Mississauga \\ 3359 Mississauga Road North \\ Mississauga, Ontario Canada L5L 1C6 \\ marion.blute@utoronto.ca
}




\section{REFERENCES}

Aldrich, Howard E., Geoffrey M. Hodgson, David L. Hull, Thorbjørn Knudsen, Joel Mokyr and Viktor J. Vanberg. 2008. In defence of generalized Darwinism. Journal of Evolutionary Economics 18: 577-596.

Altschuler, Eric L., Andreea S. Calude, Andrew Meade and Mark Pagel. 2013. Linguistic evidence supports date for Homeric epic. Bioessays 35: 417-420.

Basalla, George. 1988. The Evolution of Technology. Cambridge: Cambridge University Press.

Beinhocker, Eric D. 2006. The Origin of Wealth: The Radical Remaking of Economics and What it Means for Business and Society. Cambridge, MA: Harvard Business School Press.

Blute, Marion. 2003. The Evolutionary Ecology of Science. Journal of Memetics 7(1).

Blute, Marion. 2008. Is it time for an updated 'eco-evo-devo' definition of evolution by natural selection? Spontaneous Generations: A Journal for the History and Philosophy of Science 2:1-5.

Blute, Marion. 2010. Darwinian Sociocultural Evolution: Solutions to Dilemmas in Cultural and Social Theory. Cambridge: Cambridge University Press.

Blute, Marion. 2011. Super Cooperators? Trends in Ecology and Evolution 26: 624-625.

Blute, Marion and Paul Armstrong. 2011. The reinvention of grand theories of the scientific/scholarly process. Perspectives on Science 19(4): 391-425.

Boulding, Kenneth E. 1978. Ecodynamics: A New Theory of Societal Evolution. Beverly Hills, CA: Sage Publications.

Boulding, Kenneth E. 1981. Evolutionary Economics. Beverly Hills, CA: Sage Publications.

Buckley, Christopher D. 2012. Investigating cultural evolution using phylogenetic analysis: The origin and descent of the southeast Asian tradition of warp ikat weaving. PLOS ONE 7: 10.1371.

Cavalli-Sforza, L. L. and M. W. Feldman. 1981. Cultural Transmission and Evolution: A Quantitative Approach. Princeton, NJ: Princeton University Press.

Fanelli, Daniele. 2010. Positive results increase down the hierarchy of the sciences. PLOS ONE 5(4): e 10068.

Fanelli, Daniele. 2012. Negative results are disappearing from most disciplines and countries. Scientometrics 90: 891-904.

Gerard, R.W., Clyde Kluckhohn, and Anatol Rapoport. 1956. Biological and cultural evolution: some analogies and explorations. Behavioral Science 1: 6-34.

Guha, Ashok S. 1981. An Evolutionary View of Economic Growth. Oxford: Clarendon Press.

Hodgson, Geoffrey M. and Thorbjørn Knudsen. 2010. Darwin's Conjecture: The Search for General Principles of Social and Economic Evolution. Chicago: University of Chicago Press.

Hull, David L. 1988. Science as a Process. An Evolutionary Account of the Social and Conceptual Development of Science. Chicago: University of Chicago Press.

Ioannidis, John. 2005. Why most research findings are false. PLOS Medicine 2(8): e124. 
Jensen, Hans Siggaard, Lykke Margot Richter and Morten Thanning Vendelø, eds. 2003. The Evolution of Scientific Knowledge. Cheltenham, UK: Edward Elgar Publishing.

Krugman, Paul. 1996. What economists can learn from evolutionary theorists. Talk given to the European Association for Evolutionary Political Economy. November 1996. http://web.mit.edu/krugman/www/evolute.html

Mokyr, Joel. 2002. The Gifts of Athena: Historical Origins of the Knowledge Economy. Princeton, NJ: Princeton University Press.

Murmann, Johann Peter. 2003. Knowledge and Competitive Advantage: The Coevolution of Firms, Technology and National Institutions. Cambridge: Cambridge University Press.

Nelson, Richard R. and Sidney G. Winter. 1985. An Evolutionary Theory of Economic Change. Cambridge, MA: Belknap Press of Harvard University Press.

Petroski, Henry. 1992. The Evolution of Useful Things. New York: Vintage Books.

Pittendrigh, C.S. 1958. Adaptation, natural selection, and behavior. In Behavior and Evolution, eds. A. Roe and George G. Simpson, 390-416. Yale University Press.

Popper, Karl. 1959. The Logic of Scientific Discovery. New York: Basic Books.

Popper, Karl. 1962. Conjectures and Refutations: the Growth of Scientific Knowledge. New York: Basic Books.

Popper, Karl. 1972. Objective Knowledge: An Evolutionary Approach. Oxford: Oxford University Press.

Popper, Karl. 1974. Darwinism as a metaphysical research programme. In The Philosophy of Karl Popper, ed. P.S. Schilpp, 133-143.. Peterborough, NH: Open Court.

Rothschild, Michael. 1990. Bionomics: Economy as Ecosystem. New York: Henry Holt and Company.

Ruse, Michael. 1977. Karl Popper's Philosophy of Biology. Philosophy of Science 44: 638-661.

Schwander, Tanja and Olof Leimar. 2011. Genes as leaders and followers in evolution. Trends in Ecology and Evolution 26: 143-151.

Steadman, Philip. 1979. The Evolution of Designs: Biological Analogy in Architecture and the Applied Arts. Cambridge: Cambridge University Press.

Sterling, T.D.J. 1959. Publication decisions and their possible effects on inferences drawn from tests of significance or vice-versa. Journal of the American Statistical Association 54: 30-34.

Sterling, T.D.J., W.L. Rosenbaum and J. J. Weinkam. 1995. The effect of the outcome of statistical tests on the decision to publish and vice-versa. The American Statistician 49: 108-112.

Toulmin, Stephen E. 1972. Human Understanding: The Collective Use and Understanding of Concepts. Princeton, NJ: Princeton University Press.

Walker, Robert S., Søren Wichmann, Thomas Mailund and Curtis J. Atkisson. 2012. Cultural phylogenetics of the Tupi language family in lowland South America. PLOS ONE 7: e35025.

Yong, Ed. 2012. Replication studies: Bad copy. Nature 485: 298-300.

Ziman, John, ed. 2000. Technological Innovation as an Evolutionary Process. New York: Cambridge University Press. 